\title{
Intramedullary nailing of adult isolated diaphyseal radius fractures
}

\author{
Ahmet Köse, M.D., ${ }^{1}$ Ali Aydın, M.D., ${ }^{2}$ Naci Ezirmik, M.D., ${ }^{2}$ Murat Topal, M.D., ${ }^{2}$ \\ Cahit Emre Can, M.D., ${ }^{3}$ Sinan Yılar, M.D. ${ }^{2}$ \\ 1'Department of Orthopaedics and Traumatology, Horasan State Hospital, Erzurum-Turkey \\ 2Department of Orthopaedics and Traumatology, Atatürk University Faculty of Medicine, Erzurum-Turkey \\ ${ }^{3}$ Department of Orthopaedics and Traumatology, Çankırı State Hospital, Çankırı-Turkey
}

\begin{abstract}
BACKGROUND: The aim of the present study was to evaluate functional and cosmetic outcomes of adult patients who underwent intramedullary nailing with newly designed intramedullary radius nails for isolated radius diaphyseal fractures.

METHODS: Seventeen adult patients who had undergone intramedullary nailing for radius diaphyseal fractures were retrospectively evaluated. Patients with isolated radius diaphyseal closed fractures were included. Closed reduction was achieved in all patients. Wrist and elbow ranges of movement were calculated at final follow-up. Grip strength was calculated using a hydraulic hand dynamometer. Maximum radial bowing (MRB) and maximum radial bowing localization (MRBL) were calculated for treated and uninjured arms. Functional evaluation was performed using Grace-Eversman evaluation criteria and Disabilities of the Arm, Shoulder, and Hand (DASH) questionnaire score.
\end{abstract}

RESULTS: Of the 17 patients with isolated radius diaphyseal fractures evaluated, I I (64.7\%) were male and 6 (35.3\%) were female, with a mean age of 35.76 years (range: $23-6$ I years). Fractures were right-sided in II (64.7\%) and left-sided in 6 (35.3\%) patients. Mean time to bone union was 10.2 weeks (range: 8-20 weeks). Mean supination was $75.35^{\circ}$ (range: $67^{\circ}-80^{\circ}$ ), pronation was $85.18^{\circ}$ (range: $\left.74^{\circ}-90^{\circ}\right)$. According to Grace-Eversman evaluation criteria, results were excellent in $16(94 \%)$ and good in I $(6 \%)$ patient. Mean DASH score was 12.58 (3.3-32.5).

CONCLUSION: The gold-standard treatment of adult isolated radius diaphyseal fractures is plate and screw osteosynthesis. However, intramedullary nailing of isolated radius fractures is a good alternative treatment method, with excellent functional results and union rates similar to those of plate and screw osteosynthesis.

Keywords: Diaphyseal fracture; intramedullary nail; radius.

\section{INTRODUCTION}

Fractures of the radius that occur without fracture of the ulna are not common, due to the protective position of the ulna in direct trauma, and the abundance of protective muscle and soft tissue mass around the radius. ${ }^{[1-2]}$ The forearm bone should be considered intra-articular due to functional char-

Address for correspondence: Ahmet Köse, M.D.

Yukarı Köşk Mahallesi, Malazgirt Sokak, Doğuş Apt., A Blok,

Kat: 5, Daire: 10, Erzurum, Turkey

Tel: +90 442 - 7 II 3008 E-mail: kose.ahmet.46@hotmail.com

Qucik Response Code Ulus Travma Acil Cerrahi Derg

2016;22(2):184-191
doi: $10.5505 /$ tjtes.2015.87036

Copyright 2016

TJTES acteristics and spatial orientation. Therefore, the main aim in treatment of radius diaphyseal fractures is maintaining axial and rotational stability and preserving bone length. ${ }^{[3-5]}$ Consensus exists regarding surgical treatment of displaced isolated radius diaphyseal fractures, ${ }^{[1-5]}$ with open reduction, and plate and screw osteosynthesis accepted as the gold standard. However, there are disadvantages to plate and screw osteosynthesis, including cosmetic problems, soft tissue injury, neural injury, evacuation of fracture hematoma, and impairment of periosteal blood flow due to periosteal stripping. ${ }^{[1-3]}$

Early reports of intramedullary nailing treatment of forearm fractures described high non-union rates and unsatisfactory rotational stability, as a result of which, nailing was not a preferred method. However, the new design of intramedullary radius nails provides satisfactory functional and clinical outcomes, and the treatment method has come to be used more widely. ${ }^{[4-18]}$ 
The aim of the present study was to evaluate functional outcomes and efficiency of newly designed intramedullary radius nails in the treatment of adult isolated diaphyseal radius fractures.

\section{MATERIALS AND METHODS}

Patients who had undergone intramedullary nailing for isolated radial diaphyseal fracture were included. Informed consent was preoperatively obtained, and approval was granted by the institutional review board. Anteroposterior (AP) and lateral direct forearm radiographs were obtained on first admission following trauma. Fractures were classified according to Association for the Study of Internal Fixation (AO/ASIF) guidelines. Patients with isolated diaphyseal radial closed fractures were included. Patients with open fractures, open physeal lines, pathological fractures, Galeazzi fracture dislocations, distal radioulnar joint instabilities, neurovascular problems on initial admission, bilateral fractures, and/or multitrauma were excluded.

Bone union was evaluated according to lateral and AP radiographs obtained at final follow-up examination. Cortical trabeculation, formation of callus, radiologically observed disappearance of the fracture line, and clinical loss of tenderness with palpation over the fracture line were accepted as bone union. Absence of signs of union at the $6^{\text {th }}$ month was accepted as non-union. Angulation $>10^{\circ}$, shortening, and rotational deformities were accepted as melanin.

Maximum radial bowing (MRB) and maximum radial bowing localization (MRBL) were determined on radiography obtained on first admission and after bone union for both arms (Fig. I). Radiological and clinical evaluation of patients with implant removal was performed prior to removal.

Hand grip strength of patients with union was evaluated with a hydraulic hand dynamometer (SH500I; Saehan Inc., Masan, South Korea). Separate measurements were taken for treated and healthy forearms with the patient in a seated position, with neutral shoulders and abduction, neutral forearm and wrist, and with the elbow in $90^{\circ}$ flexion. In order to prevent muscle fatigue, measurements were taken at 3-minute intervals, and the average of 3 values was accepted as grip strength. Wrist, forearm, and elbow joint ranges of motion were measured with a goniometer. Functional evaluation incorporated Grace-Eversman evaluation criteria and Disabilities of the

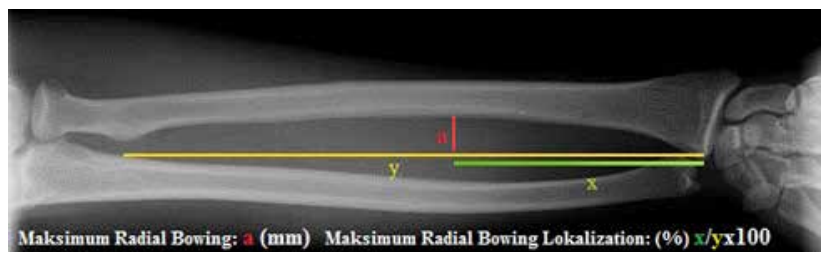

Figure 1. Schemitsch and Richards method for determining maximum radial bowing and maximum radial bowing localization.
Arm, Shoulder, and Hand (DASH) questionnaire score. ${ }^{[19]}$

\section{Surgical Technique}

Surgeries were performed with the patient in supine position. Radiolucent arm support was situated under the injured extremity. General anesthesia was applied to 12 (70.59\%) patients and regional anesthesia to 5 . Cefazolin $(2 \mathrm{gr})$ was intravenously administered 30 min prior to surgery. C-arm fluoroscopy was positioned on the fracture side to aid in reduction evaluation. Preoperative AP and lateral $x$-rays were used to ensure appropriate nail selection. Radial nail length was calculated by subtracting $3 \mathrm{~cm}$ from the distance between the radial styloid and the radial head proximal end. Appropriate nail diameter is selected with consideration of the narrowest inter-cortical distance on AP and lateral radiographs. A $10 \%$ margin of error (due to incorrect imaging) must be kept in mind while evaluating radiographs, and a range of nail sizes should be available during surgery. Closed reduction with fluoroscopic guidance was achieved in all patients. When stability was ensured with closed reduction, closed surgery was performed. At a minimum $1 \mathrm{~cm}$ proxi$\mathrm{mal}$ of the distal joint of the radius, a $1-1.5-\mathrm{cm}$ longitudinal incision was made from the dorsolateral part of the distal metaphysis (lateral to Lister's tubercle). The extensor carpi radialis longus and brevis tendons were located. The extensor carpi radialis brevis tendon sheath was longitudinally exposed with blunt dissection. First entry was performed with use of awl vertical to the radial metaphysis in the second extensor compartment. Depending upon experience and preference of the surgeon, the first, second, or fourth extensor compartments can be used as first entry point. First entry point was widened with bent awl targeting the medullary cavity. Radius nail was advanced with radius holder using rotational movements. Closed reduction was applied when nail tip reached the fracture line. Following closed reduction, the intramedullary position of the nail was verified with fluoroscopy. The distal end of the nail was advanced until full contact was made with the metaphyseal cortex, and static distal locking was performed. Passive rotational range of motion of the forearm must be evaluated following fixation.

\section{Design of the Radius Nail}

Radius nails are made of titanium alloys (TST Rakor Tıbbi Aletler San. ve Tic. Ltd., İstanbul, Turkey). A radius nail is solid and round, with a parabolic shape that angulates $10^{\circ}$ toward the anterior in the $3-\mathrm{cm}$ proximal section. It has a distal static locking screw and provides stability on the principle of 3-point fixation (Fig. 2). The distal static locking screw provides locking with $17^{\circ}$ of proximal and volar angle. This angle prevents the screw from directing toward the distal joint surface of the radius. The distal locking screw is $2.7 \mathrm{~mm}$ in diameter and has length options of $16,18,20,22$, and $24 \mathrm{~mm}$. The same nail can be used for both the right and left sides. Nail diameter may be $3,3.5$, or $4 \mathrm{~mm}$, and length may be 18,19 , $20,21,22,23$, or $25 \mathrm{~cm}$. They are used unreamed. 

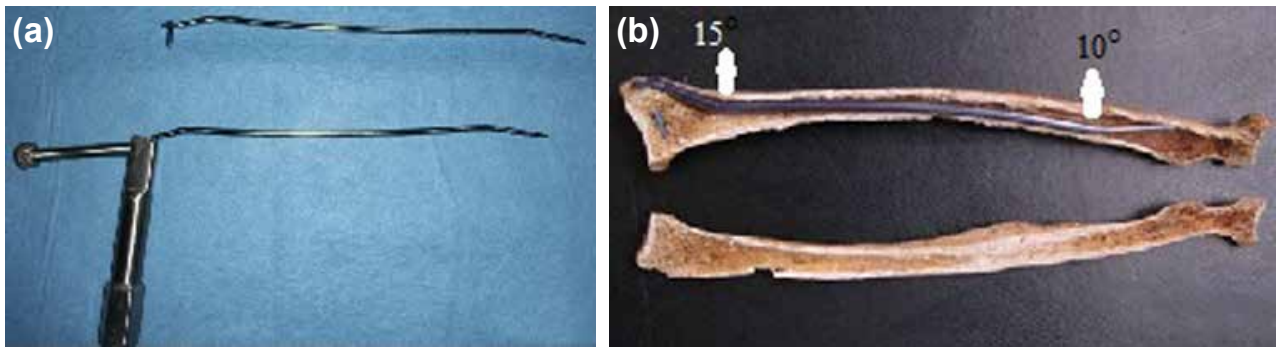

Figure 2. (a) Free radius nail and radius nail over application guide. (b) Radial nail placement on cadaveric bone model, parabolic shape of the radius nail; 10 degrees of anterior angulation of the proximal 3 $\mathrm{cm}$ and 15 anterior angulation of the distal end.

\section{Statistical Methods}

SPSS software (version 20.0; SPSS Inc., Chicago, IL, USA) was used to analyze data. Data were expressed as number, percentage, mean, and SD. Kolmogorov-Smirnov test was used to assess normal distribution of variables. Spearman's correlation analysis was used to detect correlation between parameters. Relationship between grip strength, pronation, and supination of the treated and uninjured forearms was evaluated using Mann-Whitney $U$ test. Spearman's correlation coefficient was used to analyze correlation between grip strength, pronation, and supination of the treated and uninjured forearms. A value of $p<0.05$ was considered statistically significant.

\section{RESULTS}

Of the 17 adult patients with isolated radius diaphyseal fractures evaluated, II (64.7\%) were male, and 6 (35.3\%) were female, with a mean age of 35.76 years (range: $23-61$ years). According to AO/ASIF classification, 13 (76.4\%) patients had Type A fractures, and 4 (23.6\%) had Type B fractures. Cause of fracture was a fall in 12 (70.59\%), traffic accident in $3(17.65 \%)$, and industrial accident in $2(11.76 \%)$ cases. The injury was on the right side in II (64.7\%) cases and on the left in $6(35.3 \%)$. Surgeries were performed at a mean of 16.4 (8-24) hours after initial admission. Mean duration of hospitalization was 3.1 days. Demographic information, and radiological and clinical outcomes are displayed in Table 1.

Table I. Demographic data of patients, radiological and clinical outcomes

\begin{tabular}{|c|c|c|c|c|c|c|c|c|c|c|}
\hline Patients & Age & Sex & Side & Etiology & $\begin{array}{l}\text { Immobilization } \\
\text { period (days) }\end{array}$ & $\begin{array}{c}\text { AO } \\
\text { fracture } \\
\text { type }\end{array}$ & $\begin{array}{c}\text { Outcomes } \\
\text { according to } \\
\text { Grace-Eversman } \\
\text { criteria }\end{array}$ & $\begin{array}{l}\text { DASH } \\
\text { Score }\end{array}$ & $\begin{array}{c}\text { Fluoroscopy } \\
\text { time } \\
\text { (minutes) }\end{array}$ & $\begin{array}{l}\text { Operation } \\
\text { duration } \\
\text { (minutes) }\end{array}$ \\
\hline I & 32 & $M$ & $\mathrm{R}$ & Fall & 2 & $22 \mathrm{~A} 2$ & Perfect & 26.7 & 5 & 70 \\
\hline 2 & 29 & $\mathrm{~F}$ & $\mathrm{R}$ & Fall & 3 & $22 \mathrm{~B} 2$ & Perfect & 10 & 3.3 & 40 \\
\hline 3 & 32 & M & $\mathrm{L}$ & Traffic accident & 2 & $22 \mathrm{~A} 2$ & Perfect & 4 & 1.2 & 32 \\
\hline 4 & 42 & M & $\mathrm{R}$ & Fall & 3 & $22 \mathrm{~B} 2$ & Perfect & 12 & I & 25 \\
\hline 5 & 25 & M & $\mathrm{R}$ & Fall & 3 & $22 \mathrm{~A} 2$ & Perfect & 3.3 & 2 & 30 \\
\hline 6 & 21 & $\mathrm{~F}$ & $\mathrm{~L}$ & Industrial accident & 1 & $22 \mathrm{~A} 2$ & Perfect & 4 & 1.6 & 25 \\
\hline 7 & 44 & M & $\mathrm{R}$ & Fall & 3 & $22 \mathrm{~A} 2$ & Perfect & 10 & 1.3 & 30 \\
\hline 8 & 27 & $M$ & $\mathrm{~L}$ & Fall & 5 & $22 \mathrm{~B} 2$ & Good & 32.5 & 2.7 & 25 \\
\hline 9 & 33 & $\mathrm{~F}$ & $\mathrm{R}$ & Fall & 3 & $22 \mathrm{~A} 2$ & Perfect & 5 & I.I & 20 \\
\hline 10 & 49 & $M$ & $\mathrm{~L}$ & Fall & 3 & $22 \mathrm{~A} 2$ & Perfect & 9.2 & 1 & 25 \\
\hline II & 59 & $M$ & $\mathrm{R}$ & Industrial accident & 2 & $22 \mathrm{~A} 2$ & Perfect & 17.5 & 2.3 & 24 \\
\hline 12 & 33 & M & $\mathrm{R}$ & Fall & 2 & $22 \mathrm{~B} 2$ & Perfect & 8.3 & 1 & 20 \\
\hline 13 & 51 & $M$ & $\mathrm{R}$ & Fall & 3 & $22 \mathrm{~A} 2$ & Perfect & 18.5 & 0.3 & 25 \\
\hline 14 & 26 & $\mathrm{~F}$ & $\mathrm{R}$ & Fall & 2 & $22 \mathrm{~A} 2$ & Perfect & 10 & 0.5 & 20 \\
\hline 15 & 30 & M & $\mathrm{R}$ & Fall & 2 & $22 \mathrm{~A} 2$ & Perfect & 10 & 0.5 & 20 \\
\hline 16 & 30 & $\mathrm{~F}$ & $\mathrm{~L}$ & Traffic accident & 2 & $22 \mathrm{~A} 2$ & Perfect & 17.5 & 0.5 & 20 \\
\hline 17 & 35 & $\mathrm{~F}$ & $\mathrm{~L}$ & Traffic accident & 2 & $22 \mathrm{~A} 2$ & Perfect & 17.5 & 0.2 & 17 \\
\hline
\end{tabular}

AO: Arbeitsgemeinschaft für Osteosynthesefragen; DASH: Disabilities of the Arm, Shoulder, and Hand; M: Male: F: Female; R: Right; L: Left. 
Table I. Demographic data of patients, radiological and clinical outcomes (continued)

\begin{tabular}{|c|c|c|c|c|c|c|c|c|}
\hline Patients & $\begin{array}{l}\text { Grip strength } \\
\text { (Uninjured/ } \\
\text { treated } \\
\text { forearm kg) }\end{array}$ & $\begin{array}{c}\text { Supination } \\
\text { (Uninjured/treated } \\
\text { forearm degrees) }\end{array}$ & $\begin{array}{c}\text { Pronation } \\
\text { (Uninjured/treated } \\
\text { forearm degrees) }\end{array}$ & $\begin{array}{c}\text { Elbow Flexion } \\
\text { (Uninjured/treated } \\
\text { forearm degrees) }\end{array}$ & $\begin{array}{l}\text { Maximum radial bow } \\
\text { (Uninjured/treated } \\
\text { forearm } \mathbf{~ m m} \text { ) }\end{array}$ & $\begin{array}{c}\text { Maximum radial } \\
\text { bow localization } \\
\text { (Uninjured/treated } \\
\text { forearm \%) }\end{array}$ & $\begin{array}{l}\text { Blood } \\
\text { loss } \\
(\mathrm{ml})\end{array}$ & $\begin{array}{l}\text { Time to } \\
\text { union } \\
\text { (weeks) }\end{array}$ \\
\hline I & $65.5 / 60$ & $80 / 75$ & $90 / 85$ & $143 / 140$ & $12.78 / 13$ & $57.2 / 58.2$ & 7 & 9 \\
\hline 2 & $40 / 35$ & $80 / 78$ & $90 / 87$ & $145 / 145$ & $12.5 / 13$ & $58.2 / 60$ & 10 & 10 \\
\hline 3 & $68 / 68$ & $80 / 80$ & $90 / 88$ & $143 / 143$ & $13.27 / 14.19$ & $62.2 / 64.4$ & 10 & 8 \\
\hline 4 & $70 / 65$ & $80 / 76$ & $90 / 88$ & $145 / 143$ & $13.7 / 14.2$ & $53.2 / 60.8$ & 15 & 8 \\
\hline 5 & $65 / 60$ & $80 / 70$ & $90 / 85$ & $145 / 145$ & $14 / 14.2$ & $59.2 / 60$ & 20 & 9 \\
\hline 6 & $40 / 35$ & $80 / 80$ & $90 / 90$ & $145 / 145$ & $13.56 / 13.57$ & $60.2 / 60.3$ & 10 & 8 \\
\hline 7 & $55 / 50$ & $80 / 70$ & $90 / 80$ & $145 / 138$ & $13.13 / 14$ & $58.5 / 60.1$ & 15 & 10 \\
\hline 8 & $129 / 110$ & $80 / 65$ & $90 / 74$ & $145 / 142$ & $12.1 / 14.2$ & $50 / 60.2$ & 120 & 12 \\
\hline 9 & $45 / 45$ & $80 / 78$ & $90 / 84$ & $144 / 144$ & $13.4 / 13.6$ & $57.2 / 63.3$ & 15 & 10 \\
\hline 10 & $40 / 35$ & $80 / 77$ & $90 / 83$ & $145 / 143$ & $13.3 / 13.5$ & $59.1 / 60.3$ & 10 & 10 \\
\hline 11 & $50 / 45$ & $80 / 75$ & $90 / 86$ & $145 / 140$ & $14.8 / 15$ & $57.08 / 60.7$ & 20 & 12 \\
\hline 12 & $68 / 64$ & $80 / 76$ & $90 / 86$ & $145 / 143$ & $13.7 / 14$ & $58 / 50$ & 15 & 11 \\
\hline 13 & $45 / 40$ & $80 / 75$ & $90 / 86$ & $145 / 145$ & $14.6 / 14.9$ & $49 / 59.4$ & 20 & 12 \\
\hline 14 & $35 / 33$ & $80 / 76$ & $90 / 88$ & $145 / 145$ & $13.4 / 13.7$ & $59.2 / 60.3$ & 10 & 11 \\
\hline 15 & $36 / 34$ & $80 / 77$ & $90 / 87$ & $145 / 145$ & $13.26 / 13.49$ & $60 / 60.4$ & 15 & 11 \\
\hline 16 & $48 / 44$ & $80 / 77$ & $90 / 86$ & $145 / 143$ & $13.7 / 13.9$ & $58.1 / 58.23$ & 10 & 11 \\
\hline 17 & $40 / 36$ & $80 / 76$ & $90 / 85$ & $145 / 143$ & $13.3 / 13.65$ & $57.3 / 58.17$ & 20 & 11 \\
\hline
\end{tabular}

Mean follow-up period was 38 months (range: 36-52 months). Mean duration of surgery was 27.5 minutes (range: 17-70 mins). Mean amount of blood lost during surgery was $10.3 \mathrm{ml}$ (range: 10-30 ml), with mean fluoroscopy time of I.5 mins (range: $0.2-5$ mins). Variations in duration of surgery and fluoroscopy times are shown in Fig. 3. Mean time to union was 10.2 (8-20) weeks.

Bridging callus formation was observed at the $6^{\text {th }}$ postoperative week in all patients (Figs. 4, 5). Non-union or malunion

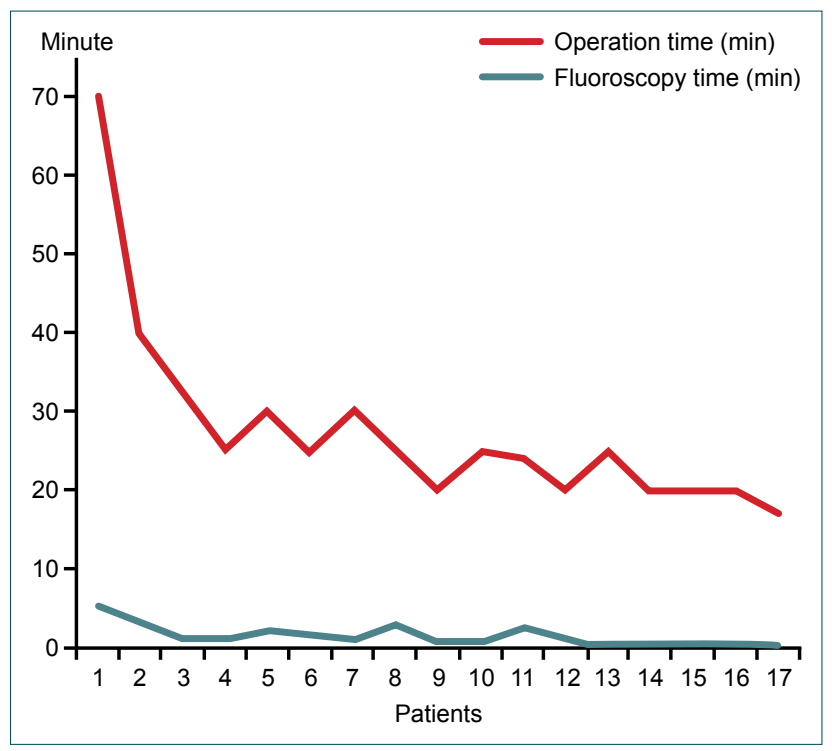

Figure 3. Variations of fluoroscopy and operation times. was not observed. Evaluation of patients according to GraceEversman functional criteria and union rates indicated excellent results in 16 patients and good results in I (Table I). Brace immobilization was applied for a mean of 2.5 (I-5) days. Immobilization was terminated when patients were able to tolerate the level of pain, and active movement was initiated.

Closed reduction was performed in all patients. No iatrogenic damage to vessels, nerves, tendons, or bone occurred. No additional postoperative fixation, due to insufficient fixation during follow-up, was needed. There were no cases of implant insufficiency, implant break, or mechanical irritation. Following union, 3 patients underwent implant removal by request at a mean of 18 months (range: 16-20 months).

Calculation of wrist and elbow range of motion was performed by goniometer. Mean supination of forearm was $75.35^{\circ}$ (range: $67^{\circ}-80^{\circ}$ ). Mean forearm pronation was $85.18^{\circ}$ (range: $74^{\circ}-90^{\circ}$ ). Mean elbow flexion was $143.05^{\circ}$ (range: $138^{\circ}-145^{\circ}$ ). Mean elbow extension was $0.64^{\circ}$ (range: $0^{\circ}-5^{\circ}$ ), mean wrist flexion was $75.2^{\circ}$ (range: $75^{\circ}-79^{\circ}$ ), and mean wrist extension was $79.17^{\circ}$ (range: $75^{\circ}-80^{\circ}$ ). No significant difference was found between the uninjured and treated arms with respect to range of motion $(p>0.05)$.

In addition, functional results were evaluated; mean DASH score was 12.58 (range: 3.3-32.5). Mean hand grip strength, calculated by hydraulic hand dynamometer, was $50.5 \mathrm{~kg}$ (range: $33-110 \mathrm{~kg}$ ). Mean MRB was $13.45 \mathrm{~mm}$ (range: 12. I$14.8 \mathrm{~mm}$ ), and mean MRBL was $57.55 \%$ (range: 49\%-64.4\%) 

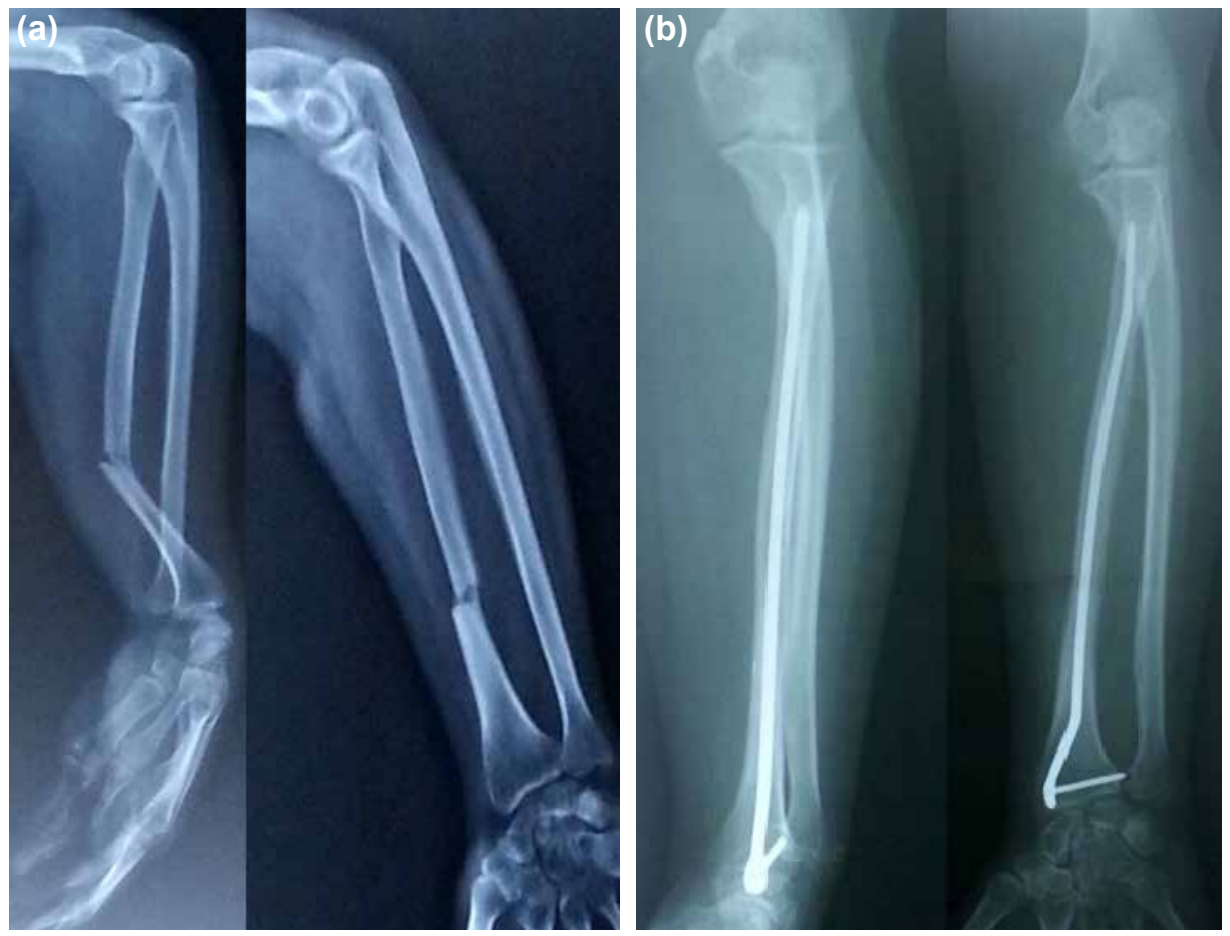

Figure 4. (a) Preoperative X-ray view of 21-year-old female with AO/ASIF Type 22A2 radial diaphyseal fracture. (b) Postoperative $12^{\text {th }}$-month X-ray view.

on radiography. Spearman's correlation analysis was used to detect correlations between functional and radiographic results of the treated forearms. No significant relationship between MRB, MRBL, pronation angle, and hand grip strength was found $(p>0.05)$. The relationship between MRB, MRBL, grip strength, pronation, and supination of treated and uninjured forearms was evaluated using Mann-Whitney $U$ test. A statistically significant difference was determined regarding MRB and MRBL $(p<0.05)$, but no significant difference was found regarding grip strength, pronation, and supination ( $p>0.05$; Table 2). A statistically significant difference in hand grip strength was found between males and females $(p<0.05)$, though not between treated and uninjured arms $(p>0.05)$.

\section{DISCUSSION}

Adult isolated radial fractures are rare. ${ }^{[4]}$ The main aim in the treatment of radius diaphyseal fractures is to maintain axial and rotational stability, and to preserve bone length. Forearm supination is provided by the rotational movement of radius over ulna. Functional anatomic reduction is mandatory for optimal rotational forearm motion. ${ }^{[-4]}$ Displaced radius diaphyseal fracture usually requires surgical treatment. ${ }^{[-18]}$
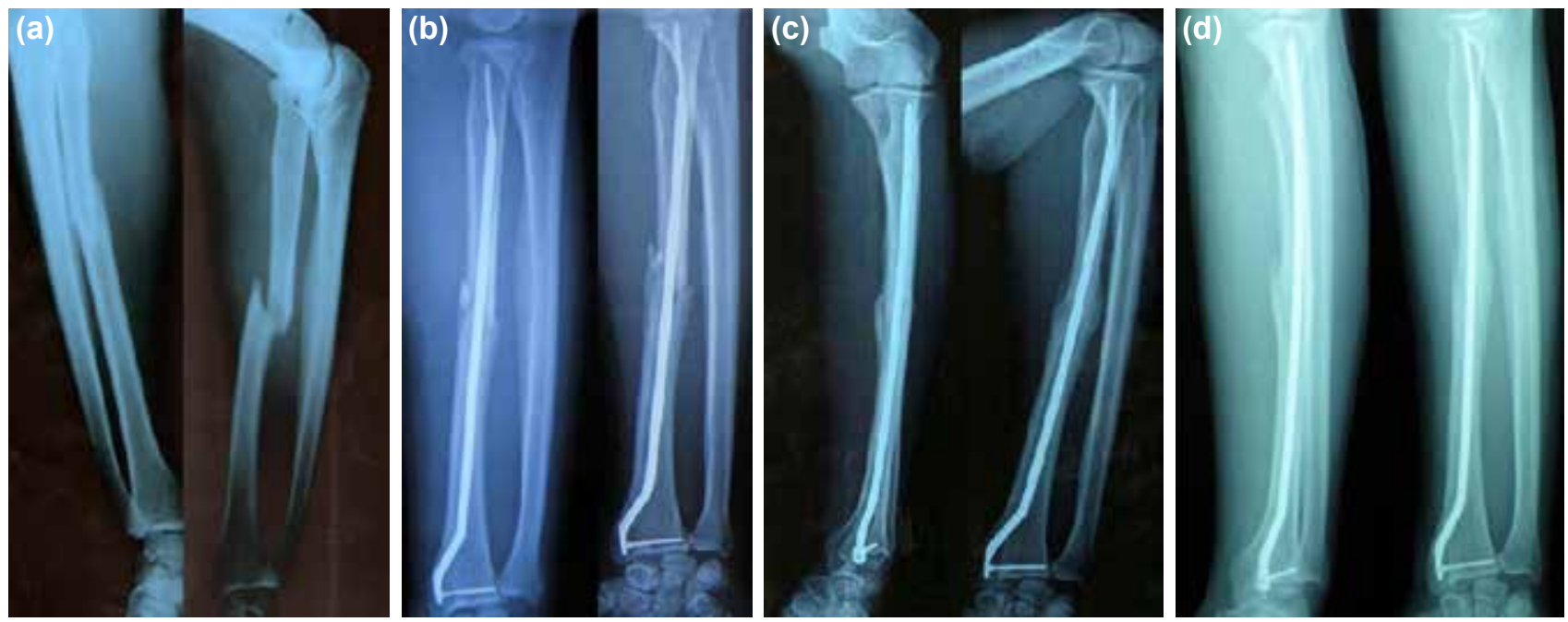

Figure 5. (a) Preoperative X-ray view of 32-year-old-male with AO/ASIF Type 22B2 radial diaphyseal fracture. (b) Postoperative $1^{\text {st-month }}$ $\mathrm{x}$-ray view. (c) Postoperative $6^{\text {th }}$-month $\mathrm{X}$-ray view. (d) Postoperative $12^{\text {th }}$-month $\mathrm{X}$-ray view. 
Table 2. Radiologic and functional results of treated and uninjured forearms

\begin{tabular}{|c|c|c|c|c|c|c|}
\hline \multirow[t]{2}{*}{ Variables } & \multicolumn{3}{|c|}{ Treated forearm } & \multicolumn{3}{|c|}{ Uninjured forearm } \\
\hline & Min.-Max. & Mean $\pm S D$ & $\mathbf{p}$ & Min.-Max. & Mean $\pm S D$ & $\mathbf{p}$ \\
\hline Grip strength & $33-110$ & $50.5 \pm 14.67$ & 0.972 & $35.00-129.00$ & $55.26 \pm 22.61$ & 0.254 \\
\hline Supination & $67-80$ & $75.35 \pm 3.80$ & 0.777 & $80-80$ & $80 \pm .0$ & 0.115 \\
\hline Pronation & $74-90$ & $85.18 \pm 3.66$ & 0.269 & $90-90$ & $90 \pm .0$ & 0.70 \\
\hline MRB & $12.10-14.80$ & $13.45 \pm .65$ & 0 & $12.78-15$ & $13.87 \pm .57$ & 0.261 \\
\hline MRBL & $49-64.40$ & $57.55 \pm 3.77$ & 0.261 & $58.17-63.3$ & $60 \pm 1.39$ & 0 \\
\hline
\end{tabular}

MRB: Maximum radial bowing; MRBL: Maximum radial bowing localization.

The most commonly used and accepted method is osteosynthesis with plate and screws. ${ }^{[1,2]}$ The number of studies that have evaluated outcome of isolated radius or isolated ulna fractures is limited. Most studies have been concerned with fractures of both bones of the forearm. ${ }^{[1-18]}$ Therefore, as the present study focuses on outcome of treatment of isolated radius fractures, it can be considered a valuable contribution to the literature.

$\mathrm{K}$-wire, ender nails, and rush nails were the fixation materials found in early reports of the intramedullary treatment of forearm fractures. In 1959, the triangular nail was the first to have been specifically designed for the forearm. ${ }^{[20]}$ However, as initial reports revealed that the nails could not provide satisfactory rotational stability and rates of non-union were high, the intramedullary nail was not widely used for the treatment of forearm diaphyseal fractures. Additional fixation material was required to provide rotational stability, such as long-arm casts, braces, or splint immobilization. More recently, a newly designed radius nail, which provides rotational stability and does not require additional fixation material, has begun to be used in the treatment of radius diaphyseal fractures. ${ }^{[4-18]}$ In the present study, a splint was used until patients could tolerate the pain, though splint immobilization was unrelated to the stability of fixation. In patients who could tolerate the pain following splinting, active movements were immediately initiated.

Restoration of radial bowing and preservation of interosseous distance is required for normal forearm function and architecture. Insufficient restoration of radial bowing causes impairment of supination and hand grip strength. ${ }^{[4]}$ Achieving anatomic reduction is more difficult in intramedullary nailing than in open reduction. ${ }^{[21]}$ The femur, tibia, humerus, and ulna have anatomic landmarks that facilitate the evaluation of rotational anatomic reduction. However, no anatomic landmarks are available in the radius to aid in the evaluation of anatomic and rotational stability reduction. ${ }^{[13]}$ The parabolic shape and titanium elastic properties of the radius nail provide rotational stabilization on a 3-point principle. ${ }^{[7-9]}$ Maintaining anatomic alignment and ensuring that cortical thickness is the same at the distal and proximal ends of the fracture are the most useful aids. ${ }^{[13]}$ Full range of motion during perioperative evaluation of passive supination and pronation after distal static locking demonstrates that exact anatomic reduction has been achieved..$^{7-9]}$

Crenshaw reported that static locking is not necessary during intramedullary nailing, ${ }^{[21]}$ as evaluation of the stability of fixation should guide the decision for static locking during surgery. ${ }^{[4]}$ Some radius nails have both proximal and distal locking options, though proximal locking carries certain risks. $[5,6,18]$ The radius has two curvatures in the sagittal and coronal planes. ${ }^{[22]}$ There is no guide that allows for both distal and proximal locking. Proximal locking is performed with freehanded technique, is made more difficult by thick muscle tissue and rotational instability, and causes increased exposure to radiation. ${ }^{[5,6]}$

Plate and screw osteosynthesis provides exact anatomic reduction with restoration of the radial bowing and radial bowing localization. ${ }^{[1,2,23]}$ However, certain evidence suggests that despite exact anatomic restoration of radial bowing and interosseous distance, limited rotational motion can be an effect of plate screw osteosynthesis. Fibrosis of the soft tissues, scarring of the skin, adhesion, shortened interosseous distance, and late mobilization can lead to limited forearm rotation. ${ }^{[5-24]}$ Differences in the restoration of radial bowing and radial bowing localization were reported in studies that compared plate and screw osteosynthesis with intramedullary nailing, though no significant differences in functional and clinical outcomes were reported. ${ }^{[10]}$ This result is most likely due to short immobilization period and early rehabilitation.

Union rates of $87 \%-98 \%$ have been reported for plate and screw osteosynthesis. ${ }^{[1-3]}$ Regarding intramedullary nailing, a bone union rate of $97 \%$ was reported by Lee et al., ${ }^{[6]} 100 \%$ by Gao et al., ${ }^{[5]}$ and $94 \%$ by Moerman et al. ${ }^{[15]}$ In the present study, the bone union rate was $100 \%$ with intramedullary nailing. ${ }^{[5-17]}$ Mean time to bone union with plate and screw osteosynthesis was reported as 7.4 weeks by Anderson et al., ${ }^{[25]}$ and as 17 weeks by Leung and Chow. ${ }^{[24]}$ Mean time 
to union with intramedullary nailing was determined as 10 (9-12) weeks in a study by Ozkaya et al., ${ }^{[16]} 3.5$ months by Weckbach et al., ${ }^{[13]}$ I 4 (9-32) weeks by Lee et al., ${ }^{[6]}$ and 10 $(7-12)$ weeks by Gao et al. ${ }^{[5]}$ Mean time to union in the present study was 10.2 (8-20) weeks. Time to bone union was similar for both methods.

Using the Grace-Eversman ${ }^{[26]}$ functional evaluation criteria, Gao et al. ${ }^{[5]}$ reported $72 \%$ excellent and good, 17\% acceptable, and II\% unacceptable results. Ozkaya et al. ${ }^{[16]}$ reported $80 \%$ excellent, $10 \%$ good, and $10 \%$ acceptable results. Visna et al. ${ }^{[2]}$ reported $88 \%$ excellent and good results, and Lee et al. ${ }^{[6]} 81 \%$ excellent, $11 \%$ good, and $8 \%$ acceptable results. In the present study, 16 (94\%) cases were categorized as excellent and I (6\%) was categorized as good. With intramedullary nailing of forearm fractures, Lee et al. ${ }^{[6]}$ reported a mean DASH score ${ }^{[19]}$ of $15(5-61)$, Gao et al. ${ }^{[5]}$ reported a mean DASH score of 19 (4-72), Lil et al. ${ }^{[17]}$ reported I 5 (4-36), and Bansal et $\mathrm{a}^{[14]}$ reported $14(8-36)$. Mean DASH score of the present study was 12.58 (3.3-32.5).

Intramedullary nailing bears certain risks, as does all treatment methods. ${ }^{[4-18]}$ The use of nails with too large a diameter can cause iatrogenic fracture, while nails with too small a diameter can cause rotational instability. ${ }^{[4]}$ Use of nails with proximal locking screws risks damaging the posterior interosseous nerve. There is risk to the extensor pollicis longus tendon and the superficial branch of the radial nerve at the point of entry of the nail. ${ }^{[18]}$ Preoperative planning and a cautious approach during surgery minimizes the rate of complications caused by inappropriate nail selection and incorrect surgical technique. ${ }^{[5]}$ No iatrogenic trauma to the bones, vessels, or nerves occurred in the present study. Use of nails without proximal locking screws removes risk of pin damage. ${ }^{\left[{ }^{9]}\right.}$ Intramedullary nailing, of proximal I/3 radius diaphyseal fractures in particular, can be considered more advantageous than plate and screw osteosynthesis.

Diverging opinions exist regarding the removal of implants used for fixation of radius diaphyseal fractures. ${ }^{[2,27,28]}$ Open and comminuted fractures, fractures caused by high energy trauma, insufficient compression and reduction in comminuted fractures, and concomitant fracture in the same extremity increase the rate of refracture. ${ }^{[27,28]}$ Removal of the implant within 8 postoperative months decreases the rate of refractures, ${ }^{[29]}$ which generally occur 2-24 months after implant removal. ${ }^{[29]}$ In plate and screw osteosynthesis, cortical atrophy may occur around the screw holes, causing high rate of refracture following implant removal. ${ }^{[2,27,29]}$ Intramedullary nailing provides firm peripheral callus, resulting in low refracture rates. ${ }^{[4]}$ Implant removal is performed via the same incision in intramedullary nailing, and even after implant removal, intramedullary nailing has better cosmetic outcomes. ${ }^{[5-17]}$ Three patients in the present population requested implant removal after bone union, though no signs of irritation were present. Implants were removed, and no refracture was observed.
Certain limitations affected the present study, including the limited number of cases that would lead to satisfactory statistical results, the short follow-up period, and the limited number of studies in the literature for comparison. Further studies that include more patients with isolated radius fractures and longer follow-up periods are warranted, as are studies that compare clinical outcomes of plate and screw osteosynthesis with those of intramedullary nailing. In order to determine the necessity of restoration of radial bowing and interosseous distance, cadaveric studies and biomechanical studies using the latest technology are necessary.

\section{Conclusion}

The newly designed intramedullary radius nails can be applied with closed reduction or with mini-open reduction, resulting in limited soft tissue injury. These nails can be applied with a shorter operating time and have better cosmetic results. They provide reliable stability, do not require additional fixation material, and allow for early active movement. Intramedullary nailing has excellent clinical and functional outcomes, and intramedullary nailing of radius diaphyseal fractures can be a reliable alternative to osteosynthesis with plate and screws.

\section{Conflict of interest: None declared.}

\section{REFERENCES}

1. Schulte LM, Meals CG, Neviaser RJ. Management of adult diaphyseal both-bone forearm fractures. J Am Acad Orthop Surg. 2014;22:437-46.

2. Henle P, Ortlieb K, Kuminack K, Mueller CA, Suedkamp NP. Problems of bridging plate fixation for the treatment of forearm shaft fractures with the locking compression plate. Arch Orthop Trauma Surg 2011;131:8591. CrossRef

3. Reilly TJ. Isolated and combined fractures of the diaphysis of the radius and ulna. Hand Clin 2002;18:179-94. CrossRef

4. Crenshaw $\mathrm{AH}, \mathrm{Zinar} \mathrm{DM}$, Pickering RM. Intramedullary nailing of forearm fractures. Instr Course Lect 2002;51:279-89.

5. Gao H, Luo CF, Zhang CQ, Shi HP, Fan CY, Zen BF.Internal fixation of diaphyseal fractures of the forearm by interlocking intramedullary nail: short-term results in eighteen patients. J Orthop Trauma 2005;19:38491. CrossRef

6. Lee YH, Lee SK, Chung MS, Baek GH, Gong HS, Kim KH. Interlocking contoured intramedullary nail fixation for selected diaphyseal fractures of the forearm in adults. J Bone Joint Surg Am 2008;90:1891-8.

7. Saka G, Saglam N, Kurtulmus T, Bakir U, Avci CC, Akpinar F, et al. Treatment of isolated diaphyseal fractures of the radius with an intramedullary nail in adults. Eur J Orthop Surg Traumatol 2014;24:1085-93. CrossRef

8. Saka G, Saglam N, Kurtulmuş T, Avcı CC, Akpinar F, Kovaci H, et al. New interlocking intramedullary radius and ulna nails for treating forearm diaphyseal fractures in adults: a retrospective study. Injury. 2014;45 Suppl 1:16-23. CrossRef

9. Köse A, Aydın A, Ezirmik N, Can CE, Topal M, Tipi T. Alternative treatment of forearm double fractures: new design intramedullary nail.Arch Orthop Trauma Surg 2014;134:1387-96. CrossRef

10. Lee SK, Kim KJ, Lee JW, Choy WS. Plate osteosynthesis versus intramedullary nailing for both forearm bones fractures. Eur J Orthop Surg 
Traumatol 2014;24:769-76. CrossRef

11. Rehman S, Sokunbi G. Intramedullary fixation of forearm fractures. Hand Clin 2010;26:391-401. CrossRef

12. Visna P, Beitl E, Pilny J, Cizmár I, Vlcek M, Kalvach J, et al. Interlocking nailing of forearm fractures. Acta Chir Belg 2008;108:333-8.

13. Weckbach A, Blattert TR, Weisser Ch. Interlocking nailing of forearm fractures. Arch Orthop Trauma Surg 2006;126:309-15. CrossRef

14. Bansal H. Intramedullary fixation of forearm fractures with new locked nail. Indian J Orthop 2011;45:410-6. CrossRef

15. Moerman J, Lenaert A, De Coninck D, Haeck L, Verbeke S, Uyttendaele $\mathrm{D}$, et al. Intramedullary fixation of forearm fractures in adults. Acta Orthop Belg 1996;62:34-40.

16. Ozkaya U, Kiliç A, Ozdoğan U, Beng K, Kabukçuoğlu Y. Comparison between locked intramedullary nailing and plate osteosynthesis in the management of adult forearm fractures. [Article in Turkish] Acta Orthop Traumatol Turc 2009;43:14-20. CrossRef

17. Lil NA, Makkar DS, Aleem AA. Results of Closed Intramedullary Nailing using Talwarkar Square Nail in Adult Forearm Fractures. Malaysian Orthop J 2012;6:7-12.

18. Fanuele J, Blazar P. Extensor pollicis longus tendon rupture in an adult after intramedullary nailing of a radius fracture: case report. J Hand Surg Am 2009;34:627-9. CrossRef

19. Hudak PL, Amadio PC, Bombardier C. Development of an upper extremity outcome measure: the DASH (disabilities of the arm, shoulder and hand) [corrected]. The Upper Extremity Collaborative Group (UECG). Am J Ind Med 1996;29:602-8. CrossRef
20. Sage FP, Smith HC. Medullary fixation of forearm fractures. J Bone Jt Surg 1957;39:91-8.

21. Crenshaw AH Jr. Fractures of shoulder girdle, arm, and forearm. In: Canale ST, Beaty JH, editors. Campbell's operative orthopaedics. 11th ed. St. Louis: Mosby; 2008. p. 3431-41. CrossRef

22. Rupasinghe SL, Poon PC. Radius morphology and its effects on rotation with contoured and noncontoured plating of the proximal radius. J Shoulder Elbow Surg 2012;21:568-73. CrossRef

23. Schemitsch EH, Richards RR. The effect of malunion on functional outcome following plate fixation of fractures of both ones of the forearm in the adult. J Bone Joint Surg Am 1992;74:1068-78.

24. Leung F, Chow SP. A prospective, randomized trial comparing the limited contact dynamic compression plate with the point contact fixator for forearm fractures. J Bone Joint Surg Am 2003;85:2343-8.

25. Anderson LD, Sisk D, Tooms RE, Park WI 3rd. Compression- plate fixation in acute diaphyseal fractures of the radius and ulna.J Bone Joint Surg Am 1975;57:287-97.

26. Grace TG, Eversmann WW Jr. Forearm fracture: treatment by rigid fixation with early motion. J Bone Joint Surg Am 1980;62:433-8.

27. Deluca PA, Lindsey RW, Ruwe PA. Refracture of bones of the forearm after the removal of compression plates. J Bone Joint Surg Am 1988;70:1372-6.

28. Labosky DA, Cermak MB, Waggy CA. Forearm fracture plates: to remove or not to remove. J Hand Surg Am 1990;15:294-301. CrossRef

29. Langkamer VG, Ackroyd CE. Internal fixation of forearm fractures in the 1980s: lessons to be learnt. Injury 1991;22:97-102. CrossRef

\section{ORIJINAL ÇALIŞMA - ÖZET}

\section{Yetişkin izole radius kırıklarında intramedüller çivi tedavisi}

\section{Dr. Ahmet Köse, ${ }^{1}$ Dr. Ali Aydın, ${ }^{2}$ Dr. Naci Ezirmik, ${ }^{2}$ Dr. Murat Topal, ${ }^{2}$ Dr. Cahit Emre Can, ${ }^{3}$ Dr. Sinan Yılar $^{2}$}

${ }^{1}$ Horasan Devlet Hastanesi, Ortopedi ve Travmatoloji Kliniği, Erzurum

${ }^{2}$ Atatürk Üniversitesi Tıp Fakültesi, Ortopedi ve Travmatoloji Anabilim Dalı, Erzurum

${ }^{3}$ Çankırı Devlet Hastanesi, Ortopedi ve Travmatoloji Kliniği, Çankırı

AMAÇ: Bu çalışmada izole radius diafiz kırı̆̆ı nedeniyle yeni dizayn intramedüller radius çivi tedavisi uyguladığımız erişkin hastalarda intramedüller çivi tedavisinin etkinliğini, fonksiyonel ve kozmetik sonuçlarını değerlendirmeyi amaçladık.

GEREÇ VE YÖNTEM: İzole deplase radius diafiz kırığı nedeniyle intramedüller çivi tedavisi uygulanan I 7 hasta geriye dönük olarak değerlendirildi. Çalışmaya kapalı izole radius diafiz kırığı olan hastalar dahil edildi. Tüm hastalara kapalı yöntemle tespit uygulandı. Hastaların son kontrollerinde gonyometre ile önkol ve dirsek hareket açıları ölçüldü. Hidrolik el dinamometresi ile sağlam ve tedavi edilen önkollar için kavrama gücü ölçüldü. Önkol direkt grafide maksimum radial eğim ve lokalizasyonları sağlam ve tedavi edilen ekstremiteler için ayrı ayrı ölçüldü. Kaynama ve fonksiyonel sonuçların değerlendirilmesi Grace-Eversman kriterleri ve Disabilities of the Arm, Shoulder and Hand (DASH) scoreanketine göre yapıldı.

BULGULAR: İzole radius diafiz kırığı olan 17 erişkin hasta değerlendirmeye alındı. Hastaların I l'i (\%64.7) erkek, altısı (\%35.3) kadındı. Yaş ortalaması 35.76 (23-6I) idi. On bir (\%64.7) hastada să̆, altı (\%35.3) hastada sol tarafta kırık vardı. Ortalama kaynama süresi 10.2 (8-20) hafta olarak değerlendirildi. Ortalama supinasyon 75.35 (67-80) derece, pronasyon 85.18 (74-90) derece idi. Grace-Eversman değerlendirme kriterlerine göre 16 (\%94) olguda mükemmel bir (\%6) olguda iyi sonuç elde edildi. Hastaların DASH ortalaması I2.58 (3.3-32.5) olarak değerlendirildi.

TARTIŞMA: Erişkin deplase radius diafiz kırıklarının cerrahi tedavisinde altın standart tedavi yöntemi plak vida osteosentezidir. Ancak fonksiyonel sonuçlarının çok iyi olması ve plak vida osteosentezine benzer kaynama oranları nedeniyle intramedüller çivi tedavisinin izole radius diafiz kırıklarında alternatif bir tedavi yöntemi olarak kullanılabileceğini düşünüyoruz.

Anahtar sözcükler: Diafizyal kırık; intramedüller çivi; radius.

Ulus Travma Acil Cerrahi Derg 2016;22(2):184-191 doi: 10.5505/tjtes.2015.87036 